\title{
PENERAPAN KOLABORASI PEMBELAJARAN STAD DAN EVERYONE IS A TEACHER HERE UNTUK MENINGKATKAN PRESTASI BELAJAR
}

\author{
Tita Pratama Zebua \\ Prodi Pendidikan Akuntansi Universitas Negeri Yogyakarta \\ titapzebua@gmail.com \\ Siswanto \\ Jurusan Pendidikan Akuntansi Universitas Negeri Yogyakarta
}

\begin{abstract}
Abstrak
Penelitian ini bertujuan untuk meningkatkan prestasi belajar pada kompetensi dasar Memahami Akuntansi Perusahaan Dagang siswa kelas X Akuntansi 2 SMK Koperasi Yogyakarta tahun ajaran 2013/2014 melalui penerapan kolaborasi model pembelajaran Student Team Achievement Division (STAD) dan Everyone is a Teacher Here. Penelitian ini merupakan penelitian tindakan kelas yang dilakukan secara kolaboratif selama dua siklus. Teknik pengumpulan data dilakukan dengan tes, observasi dan dokumentasi. Instrumen penelitian yang digunakan adalah tes prestasi belajar, lembar observasi, catatan lapangan,dan dokumentasi. Teknik analisis data adalah deskriptif kuantitatif dan kualitatif. Hasil penelitian dapat meningkatkan ketiga ranah prestasi belajar siswa. 1) Ketuntasan prestasi belajar kognitif siswa meningkat dari $50,00 \%$ siklus I menjadi $85,00 \%$ pada siklus II dengan peningkatan nilai rata-rata 24,75. 2) Prestasi belajar afektif siswa meningkat dari $36,37 \%$ siklus I mencapai kategori Sangat Baik/Baik menjadi 100\% pada siklus II. 3) Prestasi belajar psikomotor siswa meningkat dari 72,73\% siklus I mencapai nilai kategori Sangat Baik/Baik menjadi $100 \%$ pada siklus II.
\end{abstract}

Kata kunci: Student Team Achievement Division (STAD), Everyone is a Teacher Here, Prestasi Belajar, SMK Koperasi Yogyakarta

\begin{abstract}
This study aims to improve learning achievement in basic competencies Understanding of Accounting in the Trading Company of the grade of XI Accounting 2 of SMK Koperasi Yogyakarta in the academic year 2013/2014 through the implementation of collaborative learning model Student Team Achievement Division (STAD) and Everyone is a Teacher Here. This study was an class action research undertaken collaboratively for two cycles. The data collection technique was done by doingtest, observation, and documentation.The instruments of this study werelearning achievement test, observation sheets, fields notes, and documentation. The data analysis used quantitative and qualitative descriptive analysis. The results of this study show that three domains of student achievement could improve by the model. 1) Cognitive learning achievement of students increased from $50.00 \%$ in the first cycle to $85.00 \%$ in the second cycle with an increase in the average value of 24.75. 2) Affective learning achievement of students increased from $36.37 \%$ in the first cycle reached the category of Very Good/Good to 100\% in the second cycle. 3) Psychomotor learning achievement of students increased from $72.73 \%$ in the first cycle reached a value category Very Good/Good to 100\% in the second cycle.
\end{abstract}


Keywords: Student Team Achievement Division (STAD), Everyone is a Teacher Here, Learning Achievement, SMK Koperasi Yogyakarta

\section{PENDAHULUAN}

Pendidikan merupakan salah satu upaya untuk meningkatkan kualitas sumber daya manusia. Pendidikan yang berkualitas akan menghasilkan sumber daya manusia yang unggul dan berkualitas pada setiap aspek kehidupan sehingga menciptakan generasi penerus bangsa yang mampu bersaing dalam perkembangan ilmu pengetahuan dan teknologi. Hal ini diperlukan sebagai bekal dalam rangka menyongsong era globalisasi dan pasar bebas yang penuh persaingan.

Penyelenggaraan pendidikan melalui proses pembelajaran selalu menghasilkan hasil belajar. Indikator yang paling mudah untuk mengetahui kualitas penyelenggaraan pendidikan adalah prestasi belajar siswa. Nana Sudjana (2012: 22) mengemukakan bahwa, "Prestasi belajar adalah kemampuankemampuan yang dimiliki siswa setelah ia menerima pengalaman belajarnya". Saifuddin Azwar (2013: 8) juga mengungkapkan bahwa prestasi belajar secara luas mencakup ranah kognitif, ranah afektif, dan ranah psikomotor. Prestasi belajar diukur setelah siswa mengikuti proses belajar mengajar untuk mengetahui hasil belajar yang dicapai oleh siswa pada materi tertentu. Siswa dikatakan prestasi belajarnya kurang baik jika belum mampu memenuhi kriteria standar/rata-rata minimal yang biasa disebut dengan Kriteria Ketuntasan Minimal (KKM).

Prestasi belajar yang kurang baik juga ditemukan di SMK Koperasi Yogyakarta berdasarkan observasi yang dilakukan pada tanggal 15 Oktober 2013. KKM yang diterapkan di SMK Koperasi Yogyakarta untuk kelas X Akuntansi adalah 70. Tetapi harapan guru tentu siswa dapat mencapai prestasi belajar yang maksimal atau jauh melebihi KKM yang telah ditetapkan. Siswa kelas X Akuntansi 2 SMK Koperasi Yogyakarta tahun ajaran 2013/2014 berjumlah 22 siswa, dengan komposisi siswa perempuan sebanyak 19 siswa dan siswa laki-laki sebanyak 3 siswa. Data nilai siswa kelas X Akuntansi 2 SMK Koperasi Yogyakarta semester gasal tahun ajaran 2013/2014 pada mata pelajaran Akuntansi yaitunilai rata-rata ulangan harian kelas X Akuntansi 2 adalah 12 siswa atau $55 \%$ memperoleh nilai 70 100 atau sudah memenuhi KKM sedangkan sisanya 10 siswa atau $45 \%$ memperoleh nilai 30-69 atau belum mencapai KKM yang berlaku yaitu 70 . Nilai rata-rata tugas terbimbing adalah 20 
siswa atau $91 \%$ mendapatkan nilai penugasan 70-100 sedangkan 2 siswa atau 9\% mendapatkan nilai 55-69.

Data nilai siswa pada Ujian Tengah Semester (UTS) menunjukkan bahwa sebanyak 17 siswa atau $77 \%$ memperoleh nilai 70-100 sedangkan sisanya 5 siswa atau 23\% memperoleh nilai 59-69 sehingga belum mencapai KKM. Sedangkan hasil Ujian Akhir Semester (UAS) semester 1 kelas X Akuntansi 2 menunjukkan bahwa 10 siswa atau $45 \%$ memperoleh nilai 70-97 sedangkan sisanya 12 siswa atau $55 \%$ memperoleh nilai 22 69. Berdasarkan hasil observasi tersebut dapat disimpulkan bahwa kurang dari $75 \%$ siswa kelas $\mathrm{X}$ Akuntansi 2 yang telah mencapai KKM yang ditetapkan yaitu 70 .

Banyaknya siswa yang belum mampu mencapai prestasi belajar yang diinginkan yaitu minimal lebih dari $75 \%$ siswa telah mencapai KKM yang ditentukan sekolah yaitu 70 merupakan masalah yang harus segera diatasi. Apabila masalah ini tidak segera diatasi maka akan menimbulkan berbagai dampak yang kurang baik bagi pihak-pihak yang terlibat, diantaranya yaitu: 1) siswa akan sulit memahami materi pelajaran berikutnya karena materi pelajaran sebelumnya yang menjadi dasar belum dikuasai, 2) bagi sebagian siswa prestasi belajar yang rendah justru akan membuat dirinya merasa rendah diri dan membuat motivasi belajarnya menurun, 3) guru dianggap gagal dalam mendidik siswa karena prestasi siswa belum mencapai harapan, serta dampak-dampak negatif lainnya terhadap sekolah dan lingkungan masyarakat.

Rendahnya prestasi belajar siswa tersebut perlu segera diatasi dengan memperhatikan faktor-faktor penyebabnya. Faktor-faktor yang mempengaruhi prestasi belajar menurut Slameto (2010: 54-72) ada dua macam, yaitu faktor internal dan faktor eksternal. Faktor internal meliputi faktor jasmaniah, faktor psikologis dan faktor kelelahan. Sedangkan faktor eksternal meliputi faktor keluarga, faktor sekolah, dan faktor masyarakat. Masing-masing faktor yang mempengaruhi prestasi belajar memiliki karakteristik tersendiri dalam upaya perbaikannya. Prestasi belajar yang dipengaruhi oleh faktor internal berarti membutuhkan kesadaran dan kemauan dari pribadi siswa sendiri untuk memperbaikinya. Sedangkan faktor eksternal dapat diperbaiki dengan bantuan dari pihak lain seperti keluarga, sekolah, ataupun masyarakat.

Berdasarkan hasil observasi dapat diketahui pula bahwa pada proses pembelajaran guru masih lebih banyak menggunakan model pembelajaran yang 
berorientasi pada guru (teacher centered). Slameto (2010: 64) mengemukakan bahwa metode mengajar adalah suatu cara yang dipilih/digunakan oleh guru untuk menyampaian bahan pelajaran kepada siswa agar siswa dapat menerima, menguasai, dan mengembangkan bahan pelajaran itu. Metode mengajar guru yang kurang baik akan mempengaruhi belajar siswa yang tidak baik pula. Agar siswa dapat belajar dengan baik maka metode mengajar harus diusahakan yang tepat, efisisen, dan efektif. Penggunaan metode ceramah dan latihan saja pada proses pembelajaran pada dasarnya tidak cukup untuk mengembangkan kemampuan siswa sehingga dibutuhkan variasi model pembelajaran oleh guru. Keaktifan siswa dalam proses pembelajaran dapat maksimal jika model pembelajaran yang digunakan oleh guru mendukung adanya aktivitas tersebut. Aktivitas belajar sangat penting dilakukan oleh siswa dalam belajar karena pada prinsipnya belajar adalah berbuat.

Model pembelajaran kooperatif merupakan model pembelajaran yang menuntut keaktifan dan kerja sama. Baharuddin dan Esa (2007: 128) menjelaskan bawa Cooperative learning merupakan strategi belajar dimana siswa akan lebih mudah menemukan secara komprehensif konsep-konsep yang sulit jika mereka mendiskusikannya dengan siswa yang lain tentang problem yang dihadapi. Guru hanya bertindak sebagai fasilitator, memberikan dukungan tetapi tidak mengarahkan kelompok ke arah hasil yang sudah disiapkan sebelumnya.

Cooperative Learning memiliki berbagai jenis model pembelajaran yang dapat diterapkan diantaranya adalah Student Team Achievement Division (STAD) dan Every One is a Teacher Here. Isjoni (2010: 74) mengemukakan bahwa Tipe STAD merupakan model pembelajaran kooperatif yang menekankan pada adanya aktivitas dan interaksi diantara siswa untuk saling memotivasi dan saling membantu dalam menguasai materi pelajaran guna mencapai prestasi yang maksimal. Menurut Slavin (2005: 143-163) STAD terdiri atas lima komponen utama, yaitu presentasi kelas, tim, kuis, skor kemajuan individual, dan rekognisi tim. Agus Suprijono (2012: 110) mendefinisikan Everyone is a Teacher Here atau "setiap orang adalah guru" merupakan cara tepat untuk mendapatkan partisipasi kelas.

Berdasarkan permasalahan di atas maka akan dilakukan penelitian dengan judul "Penerapan Kolaborasi Model Pembelajaran Student Team Achievement Division (STAD) dan Everyone is a Teacher Here untuk Meningkatkan 
Prestasi Belajar pada Kompetensi Dasar Memahami Akuntansi Perusahaan Dagang Siswa Kelas X Akuntansi 2 SMK Koperasi Yogyakarta Tahun Ajaran 2013/2014”.

Penelitian ini bertujuan untuk meningkatkan Prestasi Belajar Akuntansi Siswa Kelas X Akuntansi 2 SMK Koperasi Yogyakarta Tahun Ajaran 2013/2014 dengan Penerapan Kolaborasi Model Pembelajaran Student Team Achievement Division (STAD) dan Everyone is a Teacher Here pada Kompetensi Dasar Memahami Akuntansi Perusahaan Dagang.

\section{METODE}

\section{Desain Penelitian}

Penelitian ini adalah Penelitian Tindakan Kelas (Classroom Action Research) dalam bentuk kolaborasi. Peneliti bersama dengan guru mata pelajaran berkolaborasi melaksanakan penelitian ini dibantu dengan beberapa observer.

\section{Subjek dan Objek Penelitian}

Subjek penelitian ini adalah siswa kelas X Akuntansi 2 SMK Koperasi Yogyakarta Tahun Ajaran 2013/2014 yang berjumlah 22 siswa. Sedangkan objek penelitian ini adalah PenerapanKolaborasi Model Pembelajaran Student Team Achievement Division (STAD) dengan
Strategi Pembelajaran Everyone is a Teacher Here untuk Meningkatkan Prestasi Belajar Kompetensi Dasar Memahami Akuntansi Perusahaan Dagang Siswa Kelas X Akuntansi 2 SMK Koperasi Yogyakarta Tahun Ajaran 2013/2014.

\section{Prosedur Penelitian}

Penelitian Tindakan Kelas ini dilaksanakan dalam dua siklus yang meliputi tahap perencanaan, pelaksanaan, pengamatan, dan refleksi pada setiap siklusnya.

\section{Teknik Pengumpulan Data dan}

\section{Instrumen Penelitian}

Teknik pengumpulan data pada penelitian ini menggunakan tes dan non tes. Tes digunakan untuk mengumpulkan data mengenai prestasi belajar kognitif siswa pada saat pelaksanaan tindakan. Muhibbin Syah (2013: 140) menjelaskan “Tes Prestasi Belajar (TPB) adalah alat ukur yang banyak digunakan untuk menentukan taraf keberhasilan sebuah proses belajar mengajar atau untuk menentukan taraf keberhasilan sebuah program pengajaran. Sedangkan non tes digunakan untuk mengumpulkan data mengenai prestasi belajar afektif dan psikomotor siswa pada saat pelaksanaan tindakan melalui observasi. Menurut Nana Sudjana (2012: 84) observasi atau 
pengamatan merupakan alat penilaian yang banyak digunakan untuk mengukur tingkah laku individu ataupun proses terjadinya suatu kegiatan yang dapat diamati, baik dalam situasi yang sebenarnya maupun dalam situasi apapun. Selain tes dan observasi juga digunakan teknik dokumentasi untuk mengumpulkan data pra penelitian berupa profil sekolah, prestasi belajar siswa sebelum pelaksanaan penelitian, perangkat pembelajaran.

Instrumen penelitian yang digunakan dalam penelitian ini adalah tes prestasi belajar, lembar observasi, dan catatan lapangan. Tes prestasi belajar meliputi pretest dan posttest pada setiap siklusnya. Pretest merupakan tes prestasi belajar yang diberikan kepada siswa sebelum pembelajaran dimulai untuk mengetahui kemampuan awal siswa. Sedangkan posttest merupakan tes prestasi belajar yang diberikan kepada siswa setelah pembelajaran terhadap serangkaian materi selesai dilaksanakan untuk mengetahui perkembangan kemampuan siswa setelah mengikuti pembelajaran. Tes prestasi belajar digunakan untuk menilai prestasi belajar kognitif siswa berdasarkan kisi-kisi terhadap Kompetensi Dasar Memahami Akuntansi Perusahaan Dagang. Lembar observasi digunakan untuk menilai prestasi belajar siswa ranah afektif dan psikomotor selama pelaksanaan pembelajaran. Penilaian pada lembar observasi mengacu pada pedoman observasi prestasi belajar afektif dan psikomotor yang dibuat sesuai dengan penerapan model pembelajaran Student Team Achievement Division (STAD) dan Every One is a Teacher Here. Selain itu juga digunakan catatan lapangan untuk merekam hal-hal penting lainnya yang ditemui selama pelaksanaan tindakan penelitian tetapi belum dapat tercatat dalam lembar observasi.

\section{Teknik Analisis Data}

Teknik analisis data yang digunakan adalah analisis deskreptif kuantitatif dengan persentase dan analisis deskriptif kualitatif. Data yang diperoleh dari hasil tes prestasi belajar dan lembar observasi adalah data kuantitatif yang menunjukkan penilaian atas prestasi belajar siswa ranah kognitif, afektif, dan psikomotor merupakan data kuantitatif. Data tersebut selanjutnya dianalisis untuk diketahui hasilnya. Langkah analisis data kuantitatif yaitu menentukan kriteria pemberian skor, melakukan penjumlahan skor, mendeskripsikan data dalam bentuk tabel, dan membuat kesimpulan. Berikut ini penjelasan langkah analisis data prestasi belajar siswa ranah kognitif, afektif, dan psikomotor melalui tes prestasi belajar dan observasi. 
1. Prestasi Belajar Siswa Ranah kognitif

a. Menghitung nilai pre-test dan posttest pada setiap siklus menggunakan rumus sebagai berikut.

Nilai $=\frac{\text { Skor Pilihan Ganda }+ \text { Soal Uraian }}{2} \times 10$

2. Prestasi Belajar Siswa Ranah Afektif dan Psikomotor

Data hasil observasi prestasi belajar afektif dan psikomotor dalam penelitian ini menggunakan skala likert yang dimodifikasi, yaitu Sangat Baik (4), Baik (3), Tidak Baik (2), dan Sangat Tidak Baik (1), (Sugiyono, 2012: 135).

a. Menghitung nilai afektif dan psikomotor siswa dari hasil observasi dihitung dengan rumus sebagai berikut.

$$
S_{k}=€ X i
$$

Keterangan:

$S_{k}=$ Skor yang diperoleh

$f x=$ Nilai setiap aspek

(Sugiyono, 2012: 49)

3. Prestasi Belajar Siswa Ranah Kognitif, Afektif, dan Psikomotor

a. Menghitung rata-rata nilai siswa pada masing-masing siklus menggunakan rumus sebagai berikut.

$$
M e=\frac{€ X i}{N}
$$

Keterangan:

$$
\begin{array}{ll}
M e & \text { : Rata-rata (Mean) } \\
€ f x & \text { : Jumlah semua nilai } \\
N & \text { : Jumlah siswa dalam satu } \\
& \text { kelas }
\end{array}
$$

(Sugiyono, 2012: 49)

b. Menghitung ketuntasan belajar (KB) dengan rumus sebagai berikut. $K B$

$=\frac{\text { jumlah siswa mencapai KKM }}{\text { Jumlah siswa dalam satu kelas }} \times 100 \%$

c. Menghitung peningkatan prestasi belajar siswa siklus I ke siklus II, yang dapat dihitung menggunakan rumus sebagai berikut.

1) Peningkatan Nilai Rata-Rata Peningkatan nilai rata-rata = Me siklus II - Me siklus I Persentase peningkatan $=\underline{\text { Me siklus II }- \text { Me siklus I }} \times 100 \%$ Me siklus I

Keterangan:

$M e=$ Rata-rata (Mean)

2) Peningkatan Ketuntasan Belajar Peningkatan ketuntasan belajar

$$
=K B \text { siklus } I I-K B \text { siklus } I
$$

Keterangan:

$\mathrm{KB}=$ Ketuntasan belajar 
Analisis data kualitatif dalam penelitian ini digunakan untuk mendeskripsikan data yang berasal dari catatan lapangan berupa seluruh catatan rangkaian pembelajaran dimana data yang diperoleh berbentuk data kualitatif. Langkah-langkah analisis data yang dilakukan dalam penelitian ini, yaitu penyajian data dalam bentuk uraian pada pelaksanaan penelitian dan penarikan kesimpulan yang disajikan pada hasil penelitian terkait pelaksanaan proses pembelajaran.

\section{HASIL DAN PEMBAHASAN}

Penerapan Kolaborasi Model Pembelajaran Student Team Achievement Division (STAD) dan Every One is a Teacher Here dilaksanakan selama dua siklus. Setiap siklus terdiri atas dua kali pertemuan. Pelaksanaan siklus I, yaitu pertemuan pertama dilaksanakan pada hari Jumat tanggal 17 Januari 2014 dan pertemuan kedua pada hari Senin tanggal 20 Januari 2014. Sedangkan pelaksanaan siklus II, yaitu pertemuan pertama dilaksanakan pada hari Selasa tanggal 21 Januari 2014 dan pertemuan kedua pada hari Jumat 24 Januari 2014. Setiap siklus telah dilaksanakan sesuai dengan tahapan penelitian tindakan kelas yaitu perencanaan, pelaksanaan, pengamatan, dan refleksi.
Pelaksanaan pembelajaran dengan menggunakan Kolaborasi Model Pembelajaran Student Team Achievement Division (STAD) dan Every One is a Teacher Here diawali dengan presentasi kelas yang dilakukan oleh guru. Penjelasan materi ini menjadikan siswa memiliki gambaran mengenai materi yang dibahas pada pembelajaran tersebut. Presentasi kelas dalam STAD menjadikan siswa menyadari bahwa mereka harus benarbenar memberi perhatian penuh selama presentasi kelas karena dengan demikian akan sangat membantu mereka dalam menyelesaikan tugas berikutnya. Kemudian siswa bekerja dalam tim. Tim mencerminkan anggota kelompok yang heterogen. Siswa dibagi dalam kelompok kecil yang beranggotakan 3-4 orang untuk menyelesaikan tugas kelompok berupa soal-soal dari guru. Tim berfungsi untuk memastikan bahwa semua anggota tim benar-benar belajar dan lebih khusus untuk mempersiapkan anggotanya untuk dapat mengerjakan kuis dengan baik. Antaranggota kelompok mereka saling bekerja sama untuk dapat mencapai skor yang tinggi dengan menyelesaikan soalsoal yang diperoleh. Tahap selanjutnya setelah berdiskusi dalam kelompok kecil yaitu Every One is a Teacher Here atau setiap orang adalah guru. Tahap ini memberikan kesempatan kepada semua 
Jurusan Pendidikan Akuntansi Indonesia, Vol. XII, No. 1, Tahun 2014

Tita Pratama Zebua \& Siswanto

$64-78$

siswa untuk mengeksplorasi kemampuan mereka dengan cara membuat soal sesuai dengan kreativitas mereka untuk dikerjakan teman lainnya. Setelah melalui beberapa tahap transformasi pengetahuan di atas siswa diberikan kuis untuk menilai pemahaman siswa setelah mengikuti proses pembelajaran. Fungsi kuis ini adalah agar setiap siswa bertanggung jawab secara individual untuk memahami materinya. Tahap yang terakhir yaitu rekognisi tim atau pemberian penghargaan yang diberikan kepada kelompok sebagai apresiasi atas usahanya untuk menguasai materi pelajaran dan memastikan bahwa teman-teman satu kelompoknya telah memahaminya pula selama satu siklus pembelajaran. Tujuan lain adalah agar semua kelompok bersungguh-sungguh dalam menyelesaikan tugas yang diberikan dan selalu berusaha menjadi yang terbaik. Penghargaan diberikan kepada setiap kelompok berdasarkan poin yang diperoleh kelompok. Poin ini mencerminkan kenaikan pengetahuan siswa setelah melalui tahap belajar individu maupun kelompok.

Berikut ini adalah data prestasi belajar kognitif siswa berdasarkan hasil penelitian pada siklus I dan II.
Tabel 1. Prestasi Belajar Siswa Ranah Kognitif Siklus I dan II

\begin{tabular}{|c|c|c|c|c|c|}
\hline \multirow[t]{2}{*}{ Kategori } & \multirow[t]{2}{*}{ Nilai } & \multirow{2}{*}{$\begin{array}{c}\text { Siklus I } \\
\text { Freku- } \\
\text { ensi }\end{array}$} & \multicolumn{3}{|c|}{ Siklus II } \\
\hline & & & $\%$ & $\begin{array}{c}\text { Freku- } \\
\text { ensi }\end{array}$ & $\%$ \\
\hline Sangat & $80-$ & 3 & 15 & 17 & 85 \\
\hline Baik & 100 & & & & \\
\hline \multirow[t]{3}{*}{ Baik } & 70 & 7 & 35 & 0 & 0 \\
\hline & - & & & & \\
\hline & 79 & & & & \\
\hline \multirow[t]{3}{*}{ Cukup } & 60 & 4 & 20 & 3 & 15 \\
\hline & - & & & & \\
\hline & 69 & & & & \\
\hline \multirow[t]{3}{*}{ Kurang } & 50 & 3 & 15 & 0 & 0 \\
\hline & - & & & & \\
\hline & 59 & & & & \\
\hline \multirow[t]{2}{*}{ Gagal } & $0-$ & 3 & 15 & 0 & 0 \\
\hline & 49 & & & & \\
\hline
\end{tabular}

Prestasi belajar siswa ranah kognitif yang disajikan pada tabel 1 di atas dapat digambarkan dalam grafik sebagai berikut. 


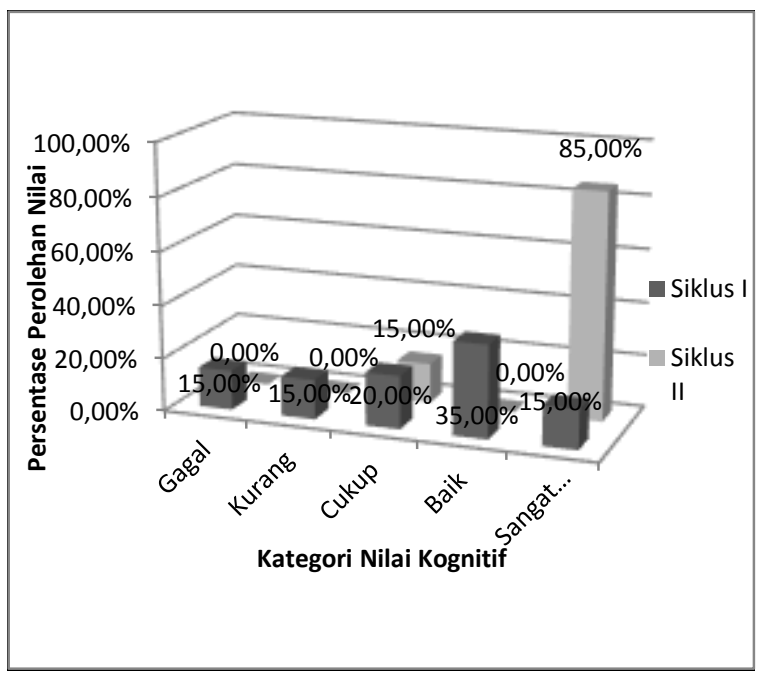

Gambar 1. Grafik Prestasi Belajar Siswa Ranah Kognitif Siklus I dan II

Keberhasilan ranah kognitif siswa terwujud jika siswa telah mampu menguasai materi yang dipelajari. Hal ini dapat dilihat dari hasil evaluasi yang dilakukan kuis/tes tertulis yang dilakukan pada setiap akhir siklus. Pada siklus I nilai rata-rata kognitif siswa satu kelas sebesar 61,25 dengan jumlah siswa yang mencapai nilai ketuntasan minimal sebanyak 10 siswa atau sebesar $50,00 \%$ dari jumlah siswa dalam satu kelas. Kemudian pada siklus II nilai rata-rata kognitif siswa meningkat menjadi 86,00 dengan jumlah siswa yang mencapai nilai ketuntasan minimal sebanyak 17 siswa atau sebesar $85,00 \%$ dari jumlah siswa dalam satu kelas yang mengikuti seluruh kegiatan pembelajaran.

Peningkatan nilai rata-rata yaitu sebesar 24,75 (40,41\%) ditunjukkan dari selisih nilai rata-rata siklus II 86,00 dan siklus I 61,25. Kemudian banyaknya siswa yang mencapai KKM juga meningkat pada siklus II yaitu sebanyak 7 siswa $(70,00 \%)$ dengan membandingkan jumlah siswa yang mencapai KKM pada siklus II sebanyak 17 siswa dan siklus I sebanyak 10 siswa. Data tersebut menunjukkan bahwa jumlah siswa yang menguasai materi pembelajaran secara tuntas $(\mathrm{N} \geq 70)$ lebih dari $75 \%$ atau 15 siswa dalam satu kelas.

Berdasarkan data prestasi belajar siswa ranah kognitif pada siklus I dan II maka dapat disimpulkan telah terjadi peningkatan prestasi belajar siswa ranah kognitif pada setiap siklus dari hasil ratarata kelas, prestasi secara individual nilai post test serta pencapaian ketuntasan belajar klasikal. Hasil pelaksanaan tindakan tersebut sesuai dengan teori yang sudah ada. Faktor-faktor yang mempengaruhi prestasi belajar siswa salah satunya adalah faktor metode mengajar guru. Guru-guru yang progresif berani mencoba metode-metode yang baru sehingga dapat membantu meningkatkan kegiatan belajar mengajar dan hasil belajar siswa. Adanya interaksi antaranggota kelompok dalam pembelajaran kooperatif dapat mengembangkan prestasi siswa. Peningkatan hasil belajar berupa peningkatan prestasi akademik merupakan 
tujuan penerapan model pembelajaran kooperatif.

Dalam ranah afektif, keberhasilan belajar terwujud apabila siswa telah mampu melakukan aspek-aspek afektif yang dituntut dalam proses pembelajaran. Hal ini dapat dilihat dari hasil observasi terkait aspek-aspek afektif siswa yang dinilai melalui pengamatan pada saat proses pembelajaran berlangsung. Aspekaspek yang diamati dalam proses pembelajaran ada 5, yaitu mendengarkan penjelasan guru, bertanya/menjawab/ memberikan pendapat saat guru menyampaikan materi, bekerja sama dalam kelompok, percaya diri saat menjelaskan kepada teman lain, serta kegigihan dan kejujuran dalam mengerjakan soal. Berdasarkan penilaian terhadap kelima aspek afektif tersebut maka siswa dikatakan telah mencapai kriteria ketuntasan belajar apabila nilai rata-ratanya dari seluruh aspek telah memperoleh nilai Sangat Baik atau Baik. Sedangkan pembelajaran dikatakan berhasil apabila minimal $75 \%$ siswa dalam satu kelas mendapatkan nilai Sangat Baik atau Baik.
Tabel 2. Prestasi Belajar Siswa Ranah Afektif Siklus I dan II

\begin{tabular}{|c|c|c|c|c|c|}
\hline \multirow[t]{4}{*}{$\begin{array}{c}\text { Kate- } \\
\text { gori }\end{array}$} & \multirow[t]{4}{*}{ Nilai } & \multicolumn{2}{|c|}{ Siklus I } & \multicolumn{2}{|c|}{$\begin{array}{c}\text { Siklus } \\
\text { II }\end{array}$} \\
\hline & & Fre & $\%$ & Fre & $\%$ \\
\hline & & kue & & kue & \\
\hline & & nsi & & nsi & \\
\hline Sangat & $16,25 \leq$ & 1 & 4,55 & 12 & 60 \\
\hline Baik & $X \leq 20,00$ & & $\%$ & & $\%$ \\
\hline Baik & $12,50 \leq X \leq$ & 7 & 31,82 & 8 & 40 \\
\hline & 16,25 & & $\%$ & & $\%$ \\
\hline Tidak & $8,75 \leq X \leq 1$ & 11 & 50,00 & 0 & 0 \\
\hline Baik & 2,50 & & $\%$ & & $\%$ \\
\hline Sangat & $5,00 \leq X \leq 8$ & 3 & 13,64 & 0 & 0 \\
\hline Tidak &, 75 & & $\%$ & & $\%$ \\
\hline Baik & & & & & \\
\hline
\end{tabular}

Prestasi belajar siswa ranah afektif yang disajikan pada tabel 2 di atas dapat digambarkan dalam grafik pada gambar 2 .

Berdasarkan tabel 2 dan gambar 2 dapat dilihat bahwa hasil tindakan pada siklus I dengan penerapan Kolaborasi Model Pembelajaran Student Team Achievement Division (STAD) dan Everyone is a Teacher Here telah mencapai kriteria yang telah ditentukan, yaitu sebanyak $36,37 \%$ atau 8 siswa dalam satu kelas yang mencapai nilai kategori Sangat Baik atau Baik dengan nilai ratarata 11,64. Pada siklus II guru berusaha untuk meningkatkan sikap afektif siswa dan berhasil dengan ketercapaian 100\% 
siswa mendapatkan nilai dengan kategori Sangat Baik atau Baik dengan nilai ratarata 17,10

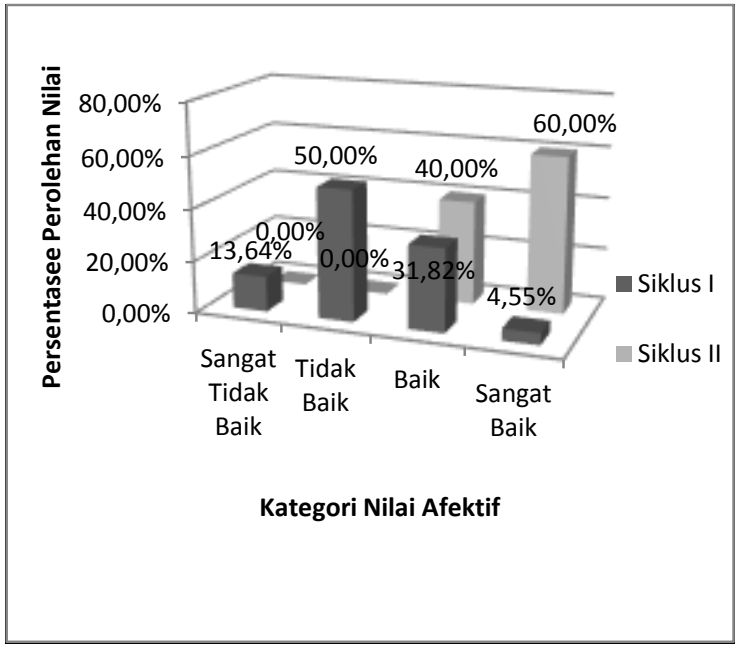

Gambar 2. Grafik Prestasi Belajar Siswa Ranah Afektif Siklus I dan II

Peningkatan nilai rata-rata yaitu sebesar 5,46 (46,91\%) ditunjukkan dari selisih nilai rata-rata siklus II 17,10 dan siklus I 11,64. Kemudian banyaknya siswa yang telah mencapai kategori Sangat Baik dan Baik juga meningkat pada siklus II yaitu sebanyak 12 siswa $(70,00 \%)$ dengan membandingkan jumlah siswa yang mencapai kategori Sangat Baik dan Baik pada siklus II sebanyak 20 siswa dan siklus I sebanyak 8 siswa (150\%). Data tersebut menunjukkan bahwa jumlah siswa yang telah tuntas lebih dari $75 \%$ atau 15 siswa dalam satu kelas.

Berdasarkan data prestasi belajar siswa ranah afektif pada siklus I dan II maka dapat disimpulkan telah terjadi peningkatan prestasi belajar ranah afektif pada setiap siklus dari hasil rata-rata kelas dan pencapaian ketuntasan belajar klasikal. Hasil pelaksanaan tindakan tersebut sesuai dengan teori yang sudah ada. Proses dalam diri individu yang berinteraksi dengan lingkungan akan menimbulkan perubahan dalam perilakunya. Proses belajar afektif memberikan perubahan dalam aspek kemampuan merasakan. Pembelajaran kooperatif mampu menambah kepercayaan, kemampuan berpikir sendiri, belajar dari siswa yang lain, mengungkapkan ide atau gagasan, dan memberdayakan siswa untuk lebih bertanggung jawab dalam belajar.

Selain ranah kognitif dan afektif, dalam prestasi belajar juga diukur ranah psikomotor siswa. Keberhasilan ranah psikomotor terwujud apabila siswa telah mampu melakukan aspek-aspek psikomotor yang dituntut dalam proses pembelajaran. Hal ini dapat dilihat dari hasil observasi terkait aspek-aspek psikomotor siswa yang dinilai melalui pengamatan pada saat proses pembelajaran berlangsung. Aspek-aspek psikomotor yang diamati meliputi aktivitas belajar siswa dalam membuat catatan hasil membaca dan penjelasan materi, kelancaran dan kejelasan menyampaikan materi, keruntutan penyampaian materi, 
ketepatan waktu dalam menyelesaikan tes, serta kerapian dalam mengerjakan tes. Siswa dikatakan telah mencapai kriteria ketuntasan belajar apabila nilai rataratanya dari seluruh aspek telah memperoleh nilai Sangat Baik atau Baik. Sedangkan pembelajaran dikatakan berhasil apabila minimal 75\% siswa dalam satu kelas mendapatkan nilai Sangat Baik atau Baik.

Tabel 3. Prestasi Belajar Siswa Ranah Psikomotor Siklus I dan II

\begin{tabular}{|c|c|c|c|c|c|}
\hline \multirow[t]{2}{*}{ Kategori } & \multirow[t]{2}{*}{ Nilai } & \multicolumn{2}{|c|}{ Siklus I } & \multicolumn{2}{|c|}{ Siklus II } \\
\hline & & $\begin{array}{l}\text { Frek } \\
\text { uensi }\end{array}$ & $\%$ & $\begin{array}{c}\text { Freku } \\
\text { ensi }\end{array}$ & $\%$ \\
\hline Sangat & 16,25 & 0 & 0 & 17 & 85 \\
\hline Baik & $\begin{array}{l}\leq \mathrm{X} \leq \\
20,00\end{array}$ & & $\%$ & & \\
\hline Baik & $\begin{array}{l}12,50 \\
\leq \mathrm{X} \leq \\
16,25\end{array}$ & 16 & $\begin{array}{l}72 \\
73 \\
\%\end{array}$ & 3 & 15 \\
\hline Tidak & 8,75 & 5 & 22 & 0 & 0 \\
\hline Baik & $\begin{array}{l}\leq \mathrm{X} \leq \\
12,50\end{array}$ & & $\begin{array}{l}73 \\
\%\end{array}$ & & $\%$ \\
\hline Sangat & 5,00 & 1 & 4,5 & 0 & 0 \\
\hline Tidak & $\leq \mathrm{X} \leq$ & & 5 & & $\%$ \\
\hline Baik & 8,75 & & $\%$ & & \\
\hline
\end{tabular}

Prestasi belajar siswa ranah psikomotor yang disajikan pada tabel $3 \mathrm{di}$ atas dapat digambarkan dalam grafik sebagai berikut.

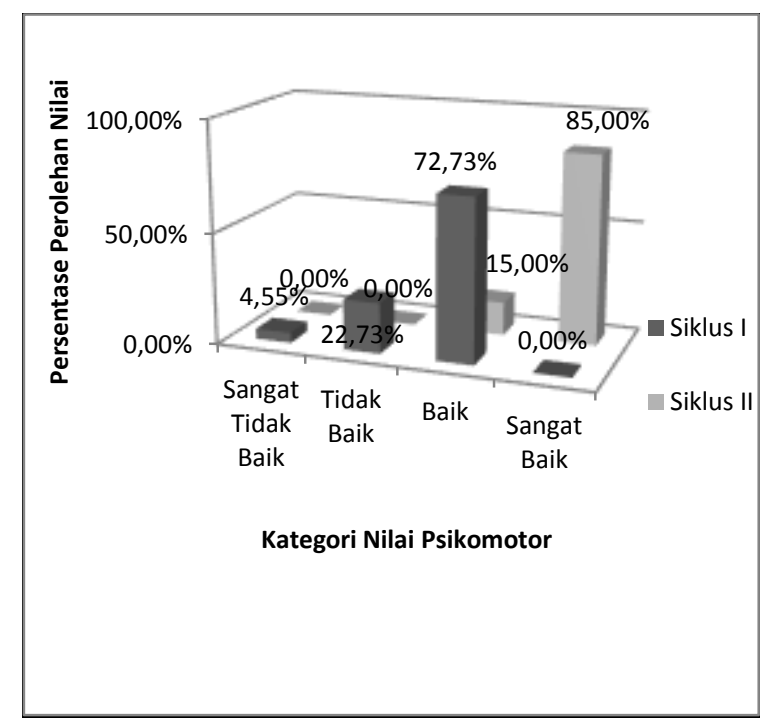

Gambar 3. Grafik Prestasi Belajar Siswa Ranah Psikomotor Siklus I dan II

Berdasarkan tabel dan grafik prestasi belajar psikomotor di atas, dapat dilihat bahwa hasil tindakan pada siklus I menjunjukkan bahwa dengan adanya penerapan Kolaborasi Model Pembelajaran Student Team Achievement Division (STAD) dan Everyone is a Teacher Here prestasi belajar psikomotor siswa. Ketuntasan klasikal untuk prestasi belajar psikomotor pada siklus I adalah 72,73\% atau 16 siswa memperoleh nilai Sangat Baik dan Baik dengan nilai rata-rata sebesar 12,86. Sedangkan ketuntasan klasikal pada siklus II adalah 100,00\% siswa memperoleh nilai psikomotor Sangat Baik dan Baik dengan nilai rata-rata 18,20. Peningkatan nilai rata-rata yaitu sebesar 5,34 (41,52\%) ditunjukkan dari 
selisih nilai rata-rata siklus II 18,20 dan siklus I 12,86. Kemudian banyaknya siswa yang telah mencapai kategori Sangat Baik dan Baik juga meningkat pada siklus II yaitu sebanyak 8 siswa $(50,00 \%)$ dengan membandingkan jumlah siswa yang mencapai kategori Sangat Baik dan Baik pada siklus II sebanyak 20 siswa dan siklus I sebanyak 16 siswa.

Berdasarkan data prestasi belajar siswa ranah psikomotor pada siklus I dan II maka dapat disimpulkan telah terjadi peningkatan prestasi belajar ranah psikomotor pada setiap siklus dari hasil rata-rata kelas dan pencapaian ketuntasan belajar klasikal. Hasil pelaksanaan tindakan tersebut sesuai dengan teori yang telah berkembang. Proses belajar mengakibatkan perubahan dalam aspek psikomotorik yaitu memberikan hasil belajar berupa keterampilan. Pembelajaran kooperatif dapat meningkatkan prestasi akademik siswa sekaligus kemampuan sosial, termasuk mengembangkan hubungan interpersonal yang positif dengan yang lain, mengembangkan keterampilan me-manage waktu, dan berpraktik memecahkan masalah tanpa takut membuat kesalahan.

\section{SIMPULAN DAN SARAN}

\section{Simpulan}

Berdasarkan hasil penelitian dan pembahasan maka dapat ditarik kesimpulan bahwa PenerapanKolaborasi Model Pembelajaran Student Team Achievement Division (STAD) dan Everyone is a Teacher Herepada Kompetensi Dasar Memahami Akuntansi Perusahaan Dagang dapat meningkatkan Prestasi Belajar Akuntansi Siswa Kelas X Akuntansi 2 SMK Koperasi Yogyakarta Tahun Ajaran 2013/2014.

1. Prestasi belajar ranah kognitif meningkat pada setiap siklusnya. Pada siklus I nilai rata-rata kognitif siswa sebesar 61,25 atau 10 siswa $(50,00 \%)$ telah mencapai KKM. Pada siklus II nilai rata-rata kognitif siswa meningkat menjadi 86,00 atau 17 siswa $(85,00 \%)$ telah mencapai KKM.

2. Prestasi belajar ranah afektif siswa meningkat setiap siklusnya. Pada siklus I sebanyak 8 siswa $(36,37 \%)$ mencapai kategori Sangat Baik atau Baik dan meningkat menjadi 100\% pada siklus II.

3. Prestasi belajar ranah psikomotor siswa meningkat setiap siklusnya. Pada siklus I sebanyak 16 siswa $(72,73 \%)$ mencapai nilai kategori Sangat Baik atau Baik dan meningkat menjadi $100 \%$ pada siklus II. 


\section{Saran}

Penelitian ini memberikan beberapa saran sebagai berikut:

1. Saran bagi Guru

a. Guru sebaiknya aktif melakukan inovasi pembelajaran dengan memperhatikan karakteristik dari materi atau kompetensi dasar yang diajarkan agar pembelajaran dapat menyenangkan dan prestasi belajar siswa dapat maksimal.

b. Guru sebaiknya menerapkan model pembelajaran kooperatif karena siswa akan lebih aktif dan mandiri dalam belajar serta dapat meningkatkan kerjasama antarsiswa.

c. Guru harus benar-benar memahami langkah-langkah pelaksanaan pembelajaran menggunakan Kolaborasi Model Pembelajaran Student Team Achievement Division (STAD) dan Everyone is a Teacher Hereagar pelaksanaannya dapat maksimal ketika guru mengimplementasikan metode ini sendiri di dalam kelas.

d. Guru hendaknya lebihcekatan dalam mengembalikan konsentrasi siswa agar siswa tidak ramai sendiri saat guru menjelaskan.

e. Guru hendaknya mampu menumbuhkan rasa percaya diri bagi siswa yang mempunyai kemampuan lemah agar bisa mengimbangi siswa lain yang mempunyai kemampuan lebih.

f. Guru hendaknya mempersiapkan media pembelajaran yang sesuai dengan materi yang disampaikan karena penggunaan media pembelajaran akan memudahkan siswa untuk memahami materi.

2. Saran Bagi Siswa

a. Siswa sebaiknya sudah siap mengikuti pembelajaran dan tidak ramai sendiri ketika kegiatan pembelajaran sudah dimulai.

b. Siswa diharapkan lebih aktif dalam proses pembelajaran karena dengan keterlibatan mereka di dalam menerima dan mengembangkan materi pelajaran akan meningkatkan prestasi belajar mereka.

c. Bagi siswa yang lemah dalam pemahaman belajar, diusahakan mempelajari materi yang akan dipelajari di rumah sebelum pembelajaran dimulai sehingga dalam semua tahap pembelajaran dapat dilalui oleh semua siswa dengan baik.

d. Bagi siswa yang kurang memiliki rasa percaya diri ketika berbicara di depan kelas sebaiknya siswa berlatih sendiri ataupun dengan teman terdekat. 
e. Siswa diharapkan untuk disiplin dalam hal kehadiran di sekolah.

\section{DAFTAR PUSTAKA}

Agus Suprijono. (2012). Cooperative Learning Teori \& Aplikasi PAIKEM. Yogyakarta: Pustaka Pelajar.

Baharuddin \& Esa Nur W. (2007).Teori Belajar \& Pembelajaran. Yogyakarta: Ar-Ruzz Media.

Isjoni \& Mohd.Arif.(2008). Model-Model Pembelajran Mutakhir. Yogyakarta: Pustaka Pelajar.
Muhibbin Syah. (2013). Psikologi Pendidikan dengan Pendekatan Baru. Bandung: Remaja Rosdakarya.

Nana Sudjana. (2012). Penilaian Hasil Proses Belajar Mengajar. Bandung: PT Remaja Rosdakarya.

Saifuddin Azwar. (2013). Tes Prestasi. Yogyakarta: Pustaka Pelajar.

Slameto. (2013). Belajar \& Faktor-Faktor yang Mempengaruhinya Edisi Revisi. Jakarta: Rineka Cipta.

Slavin, Robert E. (2005). Cooperative Learning Teori, Riset, dan Praktik. Bandung: Nusa Media.

Sugiyono. (2012). Metode Penelitian Pendidikan. Bandung: CV Alfabeta. 